\title{
浅瀬が流れや塩水の混合に及ぼす影響 THE EFFECT OF SHOAL ON FLOW AND MIXING OF DENSITY CURRENT
}

\author{
伊福 誠 $^{1} \cdot$ 吉井 勇 $^{2} \cdot$ 合田宏隆 $^{2} \cdot$ 中田正人 ${ }^{3}$ \\ ${ }^{1}$ 正会員 工博 愛媛大学助教授 工学部環境建設工学科 ( $7790-8577$ 松山市文京町 3 番) \\ ${ }^{2}$ 学生会員 愛媛大学大学院 理工学研究科 ( $7900-8577$ 松山市文京町 3 番) \\ 3 正会員 (株)エイトコンサルタント 技術開発部 (テ 700-8617 岡山市津島京町 3-1-21)
}

\begin{abstract}
Three-dimensional numerical analysis is conducted for flow and mixing of density current in a channel with several shoals. The largest amplitude of the longitudinal velocity appears on the surface in the shallowest water. Through tidal period, the transverse velocity towards the shallower water occurs at the bottom of shoal and its velocity is maxima at the low water phase. The time and depth-averaged salinity around the shoal decreases about 40-60 percent in comparison with salinity that the shoal is not mounted. The control efficiency of shoal is high for saline water intrusion.
\end{abstract}

Key Words : three-dimensional model,shoal,control of saline water intrusion, shear

\section{1.はじめに}

河口域周辺の密度流は混合型の密度流, 塩水楔, 密 度噴流の問題として数多くの研究がなされてきた. 研 究の多くは準定常状態を対象としたものであり, 非定 常状態を取り扱ったものは少ないのが実状である.し かしながら, 現地河川における塩水浸入の挙動は, 同 一河川であっても大潮時に強混合, 小潮時に緩混合形 態を示すように潮位変動によっても混合形態が変化す る.こうした塩水侵入の実態を十分に把握することは, 河川水を灌溉水や飲用水等として利用する際には極め て重要となる.

Jirka・Arita ${ }^{1}$ は, 河道内に長く侵入する塩水楔の遡 上を河口付近で阻止する技術の開発が環境水理学上の 観点から重要であるとの考えから, 河床に境界層の排 除厚さに等しい高さの堰を設置して密度流の流動形態 である塩水楔を密度カレントの流動形態に変化させる 技術の開発を進めた. しかしながら，こうした堰の設 置は比較的流下能力の低い河川に対しては治水上の問 題が懸念される.

一方, 気泡噴流は, ダムや貯水池の富栄養化防止対 策としてのエアレーションや原子炉冷却装置, オイル フェンス等の様々な工業・環境プロセスで見受けられ， これらの流動構造を解明すること極めて重要である. 小 松ら ${ }^{2)}$ は, 密度成層を形成している場に気泡噴流を用い て塩水の遡上を制御する工法を提案し，現地河川にお いて実験を行っている.この制御方法は, 河川の流下能
力を低下させることなく塩水の遡上を制御できること が利点である. しかしながら, 第一の著者は, 2 次元数 値モデルを用い，小松らの実験結果に基づいた解析を 行った結果, この制御工法は比較的高塩分の塩水遡上 に対しては効果が薄いことを明らかにし, 制御効率を 増大するには気泡発生装置から放出される気泡の量を 増大させるか, あるいは複数基の気泡発生装置が必要 であることを指摘した ${ }^{3)}$. また, この制御方法は維持管 理にかなりの手間と経費がかかることが推察される.

従来, 塩水楔の挙動を予測する数值モデルは 2 次元 がほとんどであった. しかしながら, 計算機の処理能 力の飛躍的な増大と高精度の計算手法の開発によって, 3 次元数值モデルによる解析も容易に行うことができ るようになった.

Li ら ${ }^{4)}$ は, 横断方向に水深が変化する水路において 潮位変動を伴う場合の流れの特性について 3 次元非定 常モデルを用いて検討し, 浅水部と深水部においては 時間平均した流れの大きさや向きが異なることを明ら かにしている. しかしながら, 淡水と塩水の混合にま で立ち入った解析はなされていない。

大西・田中5) は, 水路に澪を設けた室内実験によって 作漂工を用いると塩水け遡上を制御可能であり, 塩水父 換率も増大することを明らかにしている.さらに, 藤 原ら ${ }^{6)}$ は, 複断面水路における河口密度流の混合特性に ついて調べ, 低水路と高水敷の流速差により水平方向 への混合が促進されることを明らかにしている. 以上 のように, 縦横断方向の河床形状の違いによる流れの 
構造や密度流の混合特性が少しずつ明らかになりつつ ある.

こうしたことから, 本研究では, 密度流に関する 3 次元数值モデルを開発するとともに維持・管理に手間と 多額の経費を要しない浅瀬を用いた塩水遡上制御工法 を提案する. さらに, 浅瀬による塩水遡上制御効果を 数値解析的に検討し, 水環境の利用や保全に関する基 礎的資料を得ようとするものである.

\section{2. 数值計算}

(1) 支配方程式

\section{a) 運動方程式と連続の式}

流体が非圧縮性で密度は塩分のみの関数とし, Boussinesq 近似が適用できるとすると, $x$ 方向, $y$ 方向および $z$ 方向の運動量方程式は $x$ 軸を水平な基準面にとり, $y$ 軸および $z$ 軸を，それぞれ $x$ 軸と直角方向および基準面 より鈶直上向きにとると次式で与えられる.

$\frac{D u}{D t}=-\frac{1}{\rho_{0}} \frac{\partial p}{\partial x}+\frac{1}{\rho_{0}}\left(\frac{\partial \tau_{x x}}{\partial x}+\frac{\partial \tau_{y x}}{\partial y}+\frac{\partial \tau_{z x}}{\partial z}\right)$

$\frac{D v}{D t}=-\frac{1}{\rho_{0}} \frac{\partial p}{\partial y}+\frac{1}{\rho_{0}}\left(\frac{\partial \tau_{x y}}{\partial x}+\frac{\partial \tau_{y y}}{\partial y}+\frac{\partial \tau_{z y}}{\partial z}\right)$

$\frac{D w}{D t}=-\frac{\rho}{\rho_{0}} g-\frac{1}{\rho_{0}} \frac{\partial p}{\partial z}+\frac{1}{\rho_{0}}\left(\frac{\partial \tau_{x z}}{\partial x}+\frac{\partial \tau_{y z}}{\partial y}+\frac{\partial \tau_{z z}}{\partial z}\right)$

ここに, $t$ は時間, $u, v$ および $w$ は，それぞれ $x$ 方向， $y$ 方向および $z$ 方向の流速成分, $\rho_{0}$ は流体の基準密度, $\rho$ は流体の密度, $p$ は圧力, $g$ は重力加速度, $\tau_{x x}, \tau_{y x}$, $\tau_{z x}, \tau_{x y}, \tau_{y y}, \tau_{z y}, \tau_{x z}, \tau_{y z}$ および $\tau_{z z}$ は Reynolds 応力 であり, テンソル表示すると以下のように表される.

$$
\tau_{j i} / \rho_{0}=\left(\nu+\nu_{t}\right)\left(\partial u_{j} / \partial x_{i}+\partial u_{i} / \partial x_{j}\right)
$$

ここに, $\nu$ は動粘性係数である.

また, $\nu_{t}$ はSGS(subgrid-scale)の渦動粘性係数であり, 次式で与えられる7).

$$
\nu_{t}=\left(c_{s} \Delta\right)^{2}\left[\left(\frac{\partial u_{j}}{\partial x_{i}}+\frac{\partial u_{i}}{\partial x_{j}}\right) \frac{\partial u_{j}}{\partial x_{i}}\right]^{1 / 2}
$$

ここに, $c_{s}$ はSmagorinsky 定数, $\Delta=(\Delta x \cdot \Delta y \cdot \Delta z)^{1 / 3}$, $\Delta x, \Delta y$ および $\Delta z$ は, それぞれ $x, y$ および $z$ 方向の格 子間隔である.

また，連続の式は次式で与えられる.

$$
\partial u / \partial x+\partial v / \partial y+\partial w / \partial z=0
$$

\section{c) 塩分の保存式}

塩分の保存式は次式で表される.

$\frac{D S}{D t}=\frac{\partial}{\partial x}\left(K_{x} \frac{\partial S}{\partial x}\right)+\frac{\partial}{\partial y}\left(K_{y} \frac{\partial S}{\partial y}\right)+\frac{\partial}{\partial z}\left(K_{z} \frac{\partial S}{\partial z}\right)$
ここに，Sは塩分， $K_{x}, K_{y}$ および $K_{z}$ は乱流拡散係数 であり, $x, y$ および $z$ 方向の流速成分に依存すると仮定 すると次式で与えられる.

$$
\left.\begin{array}{r}
K_{x}=\gamma_{x}\left[a_{T}\left(v^{2}+w^{2}\right)+a_{L} u^{2}\right] / q \\
K_{y}=\gamma_{y}\left[a_{T}\left(u^{2}+w^{2}\right)+a_{L} v^{2}\right] / q \\
K_{z}=\gamma_{z}\left[a_{T}\left(u^{2}+v^{2}\right)+a_{L} w^{2}\right] / q \\
q=\left(u^{2}+v^{2}+w^{2}\right)^{1 / 2}
\end{array}\right\}
$$

ここに, $\gamma_{x}, \gamma_{y}$ および $\gamma_{z}$ は正の係数, $a_{T}, a_{L}$ は乱流拡 散倸数に寄与する特性長であり, 次式で与える.

$$
a_{T}=(\Delta x \cdot \Delta y \cdot \Delta z)^{1 / 3}, \quad a_{L}=c_{1} \cdot a_{T}
$$

ここに, $c_{1}$ は正の係数である.

d) 状態方程式

状態方程式は次式で表される.

$$
\rho / \rho_{0}=1+\beta S, \quad \beta=\left(\rho_{s}-\rho_{0}\right) / \rho_{s}
$$

ここに, $\rho_{s}$ は, 塩水の密度である.

\section{（2）初期条件および境界条件}

初期条件は, 静水位の状態とする. 下流, 上流, 底 面, 自由水面および側方境界においては, 以下のよう な境界条件を課す。

a) 下流

水面変動量 $\eta$ は次式で与える.

$$
\eta(t)=a \sin \sigma t
$$

ここに, $a$ は潮汐の振幅, $\sigma$ は角周波数 $(\sigma=2 \pi / T, T$ : 潮 汐の周期) である.

$x, y$ およひ $z$ 方向の流速成分には以下の条件を課す.

$$
\partial^{2} u / \partial x^{2}=0, \quad v=w=0
$$

また，塩分は上げ潮時および下げ潮時において以下の 条件を課す。

$$
\left.\begin{array}{l}
S=S_{0} G(t) \quad(\text { flood }: u>0) \\
G(t)=1-(1-\sin \sigma t) S^{\prime} \\
\partial^{2} S / \partial x^{2}=0 \quad(\text { ebb }: u<0)
\end{array}\right\}
$$

ここに, $S_{0}$ は塩分, $S^{\prime}$ は重み係数である.

b) 上流

流速分布は次式で表す対数則分布を仮定する.

$$
\begin{aligned}
& u=u_{\xi}\left[\ln \left\{(e-1)\left(z-z_{b}\right) /\left(\xi-z_{b}\right)+1\right\}\right] \\
& v=w=0 \\
& \left.\partial^{2} S / \partial x^{2}=0\right\}
\end{aligned}
$$

ここに, $u_{\xi}$ は水面における $x$ 方向の流速成分, $e$ は自然 対数の底, $\xi$ は基準面から自由水面までの高さである. 
c) 底面

$$
\left.\begin{array}{rl}
u=v=w & =0 \\
K_{x}(\partial S / \partial x)\left(\partial z_{b} / \partial x\right)-K_{z}(\partial S / \partial z) & =0
\end{array}\right\}
$$

d) 自由水面

$$
\left.\begin{array}{r}
p=0 \\
w_{\xi}=\partial \xi / \partial t+u_{\xi}(\partial \xi / \partial x)+v_{\xi}(\partial \xi / \partial y) \\
\partial u / \partial z=0, \quad \partial v / \partial z=0 \\
K_{x}(\partial S / \partial x)(\partial \xi / \partial x)-K_{z}(\partial S / \partial z)=0
\end{array}\right\}
$$

ここに, $u_{\xi}, v_{\xi}$ および $w_{\xi}$ は, 水面における $x, y$ および $z$ 方向の流速成分である.

e) 側方境界

$$
u=v=w=0, \quad \partial S / \partial y=0
$$

\section{(3) 座標変換および变数変換}

自由水面の時・空間的変動や底面の空間的変化のた め, 対象とする数值解析領域は必ずしも直方体ではな い. 解析領域を直方体として取り扱うと, 境界におけ る取り扱いが容易になり, 領域内の流れ場をうまく記 述するのに好都合である. そこで, 対象とする物理座 標に対して次式のような座標変換を行う.

$$
\left.\begin{array}{r}
z^{\prime}=\left(z-z_{b}\right) f_{b}(x, y, t) \\
f_{b}(x, y, t)=1 /\left(\xi(x, y, t)-z_{b}(x, y, t)\right.
\end{array}\right\}
$$

ここに， $z_{b}$ は基準面から底面までの高さである．

座標変換によると従属変数が $(x, y, z, t)$ から $\left(x, y, z^{\prime}, t\right)$ に変わり, 座標による微分は以下のようになる。

$$
\left.\begin{array}{r}
\partial / \partial t=\partial / \partial t+F_{1} \partial / \partial z^{\prime}, \quad \partial / \partial x=\partial / \partial x+F_{2} \partial / \partial z^{\prime} \\
\partial / \partial y=\partial / \partial y+F_{3} \partial / \partial z^{\prime}, \partial / \partial z=F_{4} \partial / \partial z^{\prime}
\end{array}\right\}
$$

なお, $F_{1}, F_{2}, F_{3}$ および $F_{4}$ は, 次式のように表される.

$$
\left.\begin{array}{r}
F_{1}=z^{\prime} / f_{b}\left(\partial f_{b} / \partial t\right)-f_{b}\left(\partial z_{b} / \partial t\right) \\
F_{2}=z^{\prime} / f_{b}\left(\partial f_{b} / \partial x\right)-f_{b}\left(\partial z_{b} / \partial x\right) \\
F_{3}=z^{\prime} / f_{b}\left(\partial f_{b} / \partial y\right)-f_{b}\left(\partial z_{b} / \partial y\right) \\
F_{4}=f_{b}
\end{array}\right\}
$$

この座標変換を運動量方程式, 連続の式, 水面形の 方程式および塩分の保存式に適用し，流れ場や塩分の 時・空間的変動を計算する.

\section{3. 解析結果}

（1）小松ら ${ }^{2)}$ の実験に基づく解析

解析では，小松らが室内実験で用いた水路のうち海
域部と潮汐発生装置を除いた水路を対象とする(図-1).

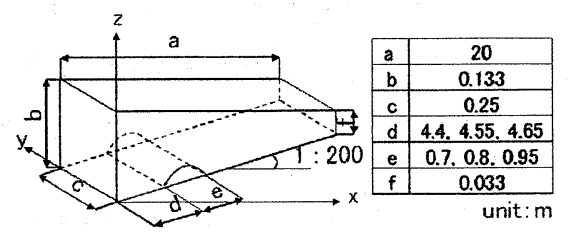

\section{図-1 解析に用いた水路}

図-2に底設する浅瀬を示す. 浅瀬頂部の高さは $3 \mathrm{~cm}$ で頂部が水路中央と側壁にあり, 頂部から翼状に伸びて いる部分と $x$ 軸とのなす角度が 30,45 および $90^{\circ}$ の 3 通り, 横断方向に浅瀬の断面が一定の場合の 11 通りを 対象とした。 また，下流側境界の塩分は 3 および $5 \%$, 潮汐の振幅は $0.7 \mathrm{~cm}$, 周期は $240 \mathrm{~s}$, 上流境界における 淡水流入量は $50 \mathrm{ml} / \mathrm{s}$ である. $x$ および $y$ 方向の格子間隔 は, それぞれ $5 \mathrm{~cm}$ および $2.5 \mathrm{~cm}$, 鉛直方向は 10 分割し, 時間刻み $\Delta t$ は潮汐の周期を 8000 等分し, 20 周期計算し た. 式(5) 中の Smagorinsky 定数は $0.1^{8)}$, 式(8) 中の $\gamma_{x}$, $\gamma_{y}$ および $\gamma_{z}$ は、それぞれ $0.1,3 \times 10^{-3}$ および $3 \times 10^{-3}$, 式 (9) 中の $c_{1}$ は 50, 式(13)中の $S^{\prime}$ は 0.1 とした.

解析に用いた浅瀬のうちで塩水遡上の制御効果が最大 であったのは図-2(a) で最浅部から下流に向けて翼状に 伸びている部分とx 軸とのなす角度が $30^{\circ}$ の場合 (以後, type-a30 と記す) であった. 以後の考察には, type-a30 と横断方向に浅瀬の断面が一定の場合 (以後, type-x90 と記す）の解析結果を用いる.

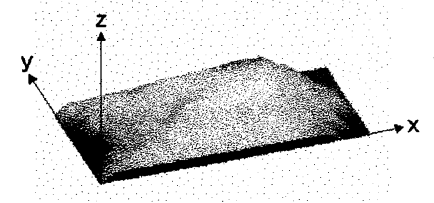

(a)type-a30 (b)type-b30
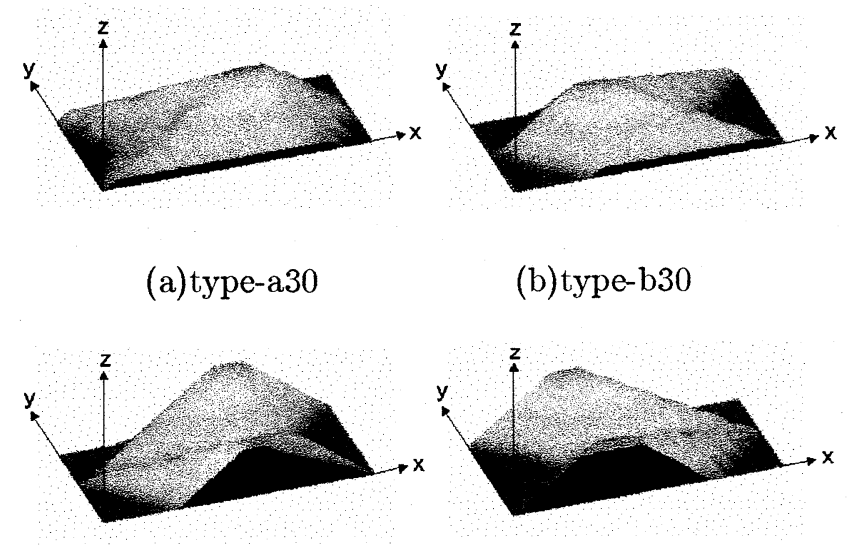

(c)type-c30

(d)type-d30

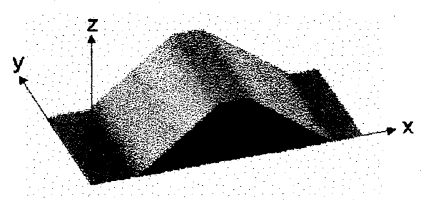

(e)type-x90

図-2 解析に用いた浅瀬の形状例 


\section{（2）浅瀬周辺の流れ}

図-3は, 上流向きの流速が最大となる位相（以後, MFV と記す）における type-a30 とx90 の浅瀬周辺の流 速ベクトルを示す，なお，下流側境界における塩分は $3 \%$ であり, 図中の破線は構造物の底設，(a) と(b) は 水路中央における結果，(c) と (d) は構造物を底設しな い場合の水路床より $3 \mathrm{~cm}$ の高さにおける結果である. (a) と (b) を比較すると, 両 type とも $x=5 \mathrm{~m}$ 付近におい て流速は最大となり, 最大流速は水深の $2 / 3$ 程度の深さ で生じている. また, type-a30の $x=5.25 \mathrm{~m}$ 付近では水 平方向流速はかなり小さいものの, type-x90では浅瀬 の頂部とほぼ同程度である.さらに, type-a30の浅瀬 頂部付近においては, 鈶直方向流速が大きくなってい る.なお, 浅瀬の下流側と $x=6 \mathrm{~m}$ 付近より上流側での 流速は両 type ともほぼ同一である. 一方, (c) と (d) を比較すると, type-a30 の場合, 構造物の下流側では 構造物の稜線に沿うように流れが収束し，また，構造 物の上流側では逆に稜線に沿って流れは発散している. type-x90 の場合, 構造物の下流側では流れが収束して いるが, type-a30 と比較するとその度合いは小さい. な お，側壁付近を除けば，構造物の上流側における縦断 方向流速はtype-a30より大きい. 2 次元構造物と 3 次元 構造物の底設が流れに及ぼす影響は，構造物の上流側 法尻において顕著である.こうした，縦断・横断方向の 流速の歪みの大小は塩水の混合に影響を及ぼすと考える.

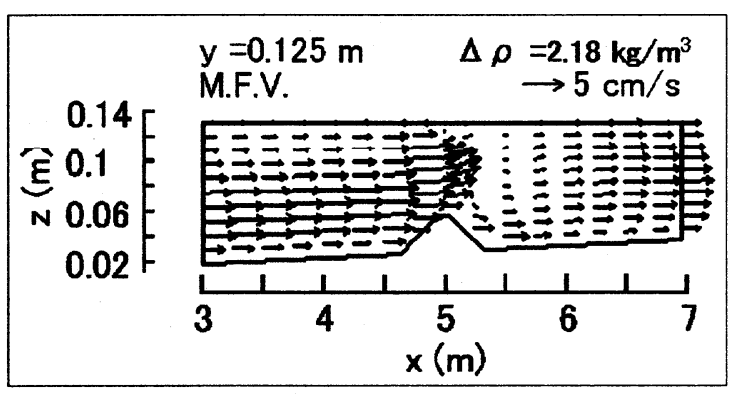

(a) type-a30(u-w)

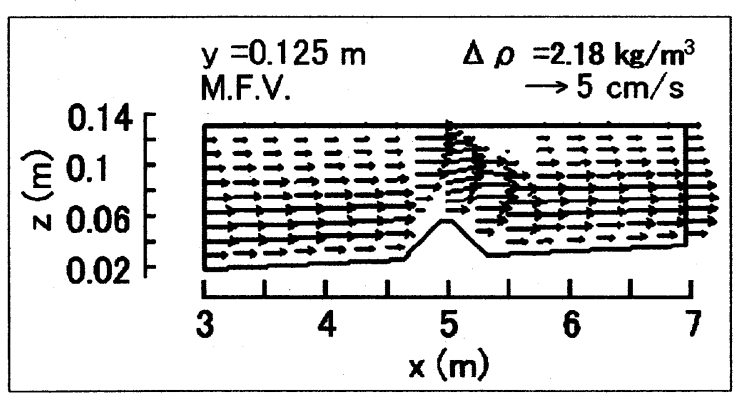

(b) type-x90(u-w)

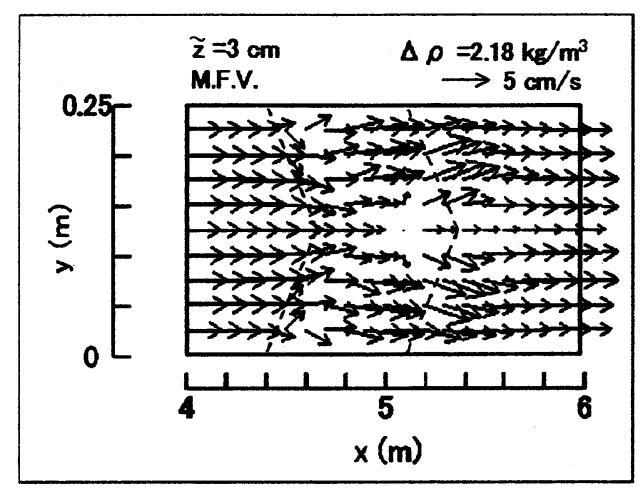

(c) type-a30(u-v)

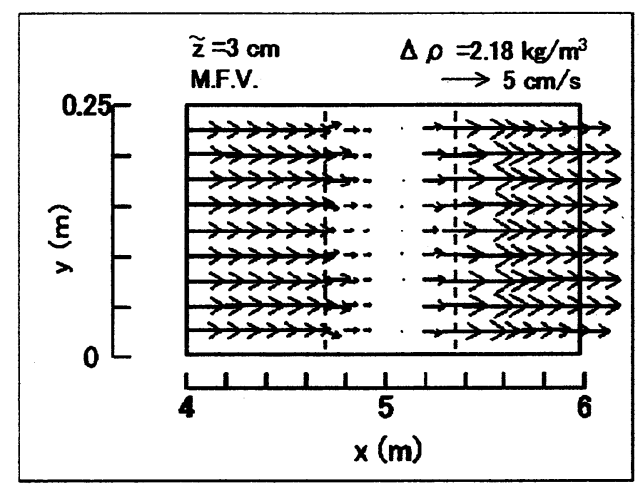

(d) type-x90(u-v)

図-3 MFVの位相における浅瀬周辺の流速ベクトル

図-4は, $x=5 \mathrm{~m}$ での MFVにおける横断方向流速(v) の分布を示したものであり，(a)および(b)は，それぞれ type-a30 およびx90 の結果である. なお， $y=0 \mathrm{~m}$ から 水路中央に向かう流れが正, $y=0.25 \mathrm{~m}$ から水路中央に 向かう流れが負であり，上流からみたものである. (a) では, 底面付近では深部から浅部へ，水面付近では水路 中央から側壁へ向かう水深スケールの循環流が存在す る. また, $y=0.1 \mathrm{~m}$ の底面付近においては, 潮汐の一 周期間を通して流向は変化しないが，水面付近では上 げ潮時および下げ潮時には，それぞれ側壁および水路 中央に向かう流れが生ずる． $\mathrm{Li}^{9}{ }^{9}$ は，対称な横断面を有 する水路を対象とした解析から, 満潮時（以後, HWS と記す）および干潮時には，横断方向流速は，それぞれ 深部から浅部および深部から浅部へ向かうこと, 流速 振幅は位相とともに変化することを指摘している．前 述したように, 本解析での結果は水深によって流れの 時間変化が異なる. $\mathrm{Li}$ との差は, 水路床の形状に起因 するのではないかと考える. (b) では, 側壁から水路中 央に向かう流れが存在し, 流速振幅は $y=0.05$ あるいは $0.2 \mathrm{~m}$ 付近の水面において最大となる. (a) と比較する と, 水面および底面付近の流速振幅は, それぞれ $1 / 3 お$ よび $1 / 5$ 程度でありかなり小さく, 流況も異なる. 


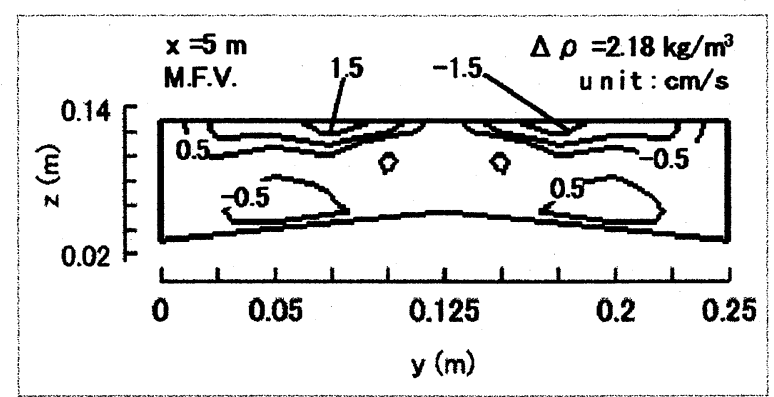

(a) type-a30

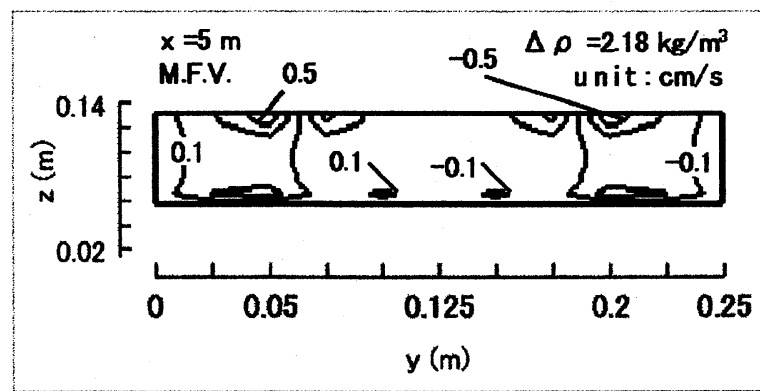

(b) type-x 90

図-4 MFVの位相における横断方向流速

\section{（3）満潮時における構造物周辺の塩分}

図-5 は，塩水の遡上距離が最大となる HWS における 塩分の空間分布を示したものであり，(a)，(b) および(c) は，それぞれ浅瀬がない場合，type-a30およびx90の場 合である.なお，下流側境界における塩分は $3 \%$ であ り，水路中央に相当する.

(a) では，底面近傍には，下流側境界の塩分の $80 \%$ 以 上の淡塩混合水が存在し, 成層化が顕著である.また, 水面近傍においては下流側境界の塩分の $1 / 3$ 程度の比較 的高塩分の淡塩混合水が存在する. (b) では, 浅瀬に誘 起される鉆直流の影響を受けて比較的高塩分の淡塩混 合水が水面近傍まで舌状に拡がり，鈶直混合が顕著であ る. (a) での底面における $S / S_{0}=0.5$ の等塩分線の位置 は $x=9.5 \mathrm{~m}$ 付近であり, 浅瀬の設置により $4.5 \mathrm{~m}$ 程度 侵入距離が短くなっている. 一方, (c) では, 浅瀬の下

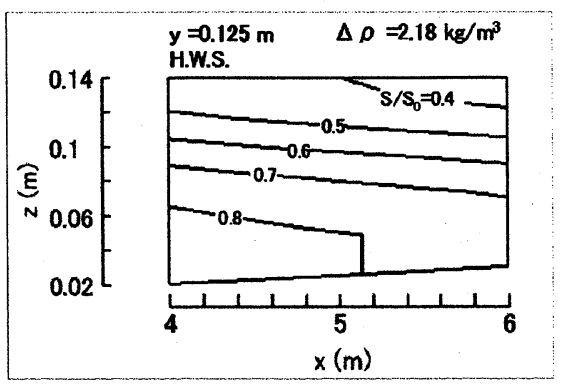

(a) 浅瀬なし

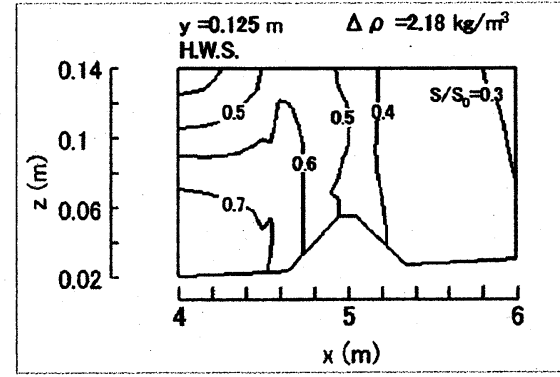

(b) type-a30

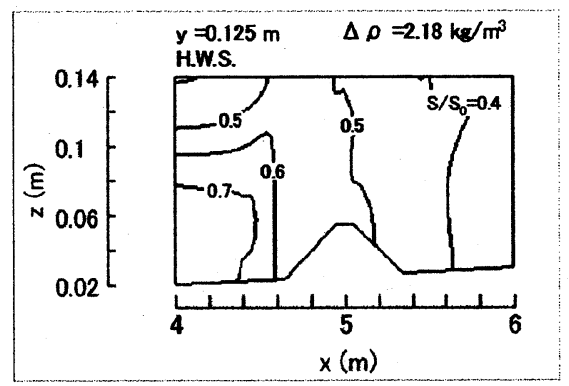

(c) type-x90

図-5 HWS の位相における等塩分線

流側では(b) とほぼ似た傾向を示すが，上流側では(b) よりも等塩分線の侵入距離が長くなっている.このこ とは，図-3あるいは图-4に示すように，流速勾配ある いは横断方向の流速振幅の増大によって水平方向の混 合が強くなることに起因すると考える.

\section{（4）時間および水深平均した塩分の空間分布}

図-6は，水路中央および側壁から $2.5 \mathrm{~cm}$ における時 間および水深平均した塩分の空間分布を示したもので あり，図中の黒三角間は浅瀬の設置範囲である.なお， 下流側境界における塩分は $3 \%$ である. 最浅部から翼 状に伸びている部分と $\mathrm{x}$ 軸とのなす角度が $30^{\circ}$ の 4 通 りと type-x90 の結果を小松らの実験結果, 小松らの実 験結果に基づく解析結果とともに示している.

(a)の水路中央におけるけっかをみると, 浅瀬がない場 合, 浅瀬の設置下流端である $x=4.4$ および上流端である $5.35 \mathrm{~m}$ における $S / S_{0}$ は，それぞれ 0.52 および 0.46 程度 である. 一方, 浅瀬を設置した場合，いずれの場合とも， $x=3 \mathrm{~m}$ 付近から塩分は急激に低下している. また, $x=3$ $\mathrm{m}$ 付近の塩分 $S / S_{0}$ は, type-a $30, \mathrm{~b} 30, \mathrm{c} 30$ および $\mathrm{d} 30$ では，それぞれ $0.61 ， 0.72 ， 0.68$ および 0.68 程度であっ たものが, $x=5.35 \mathrm{~m}$ では，それぞれ $0.27,0.46,0.41$ および 0.38 程度であり $2 / 5-3 / 5$ に低下している. 一方, (b) をみると，塩分の分布は (a) とよく似た傾向を示し， type-a30の場合が塩水遡上の制御効果が最も高い. 


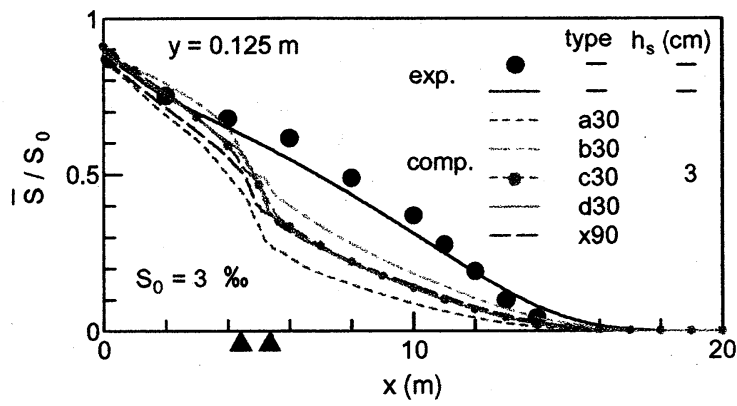

(a) $y=0.125 \mathrm{~m}$

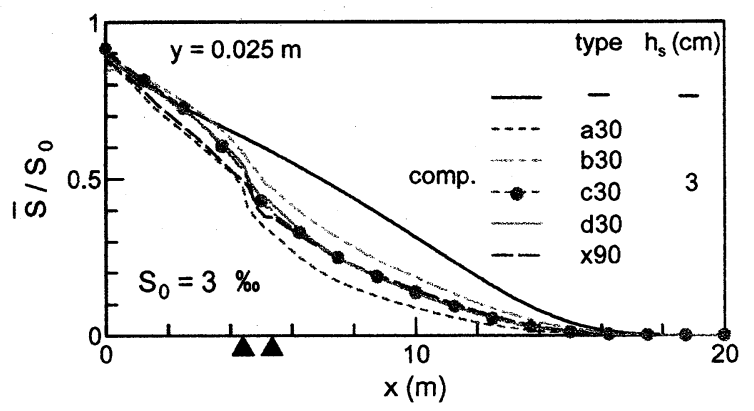

(b) $\mathrm{y}=0.025 \mathrm{~m}$

図-6 時間・水深平均した塩分 $(\boldsymbol{\Delta}-\mathbf{A}$ :浅瀬の設置範囲 $)$

図-7は，浅瀬がない場合の時間および水深平均した 塩分に対する type-a30およびx90のそれらの空間分布

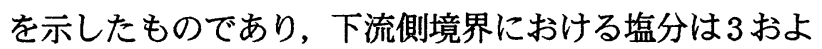
び5\%である. 下流側境界の塩分が $5 \%$ の場合, 制御 効率が若干悪くなってはいるものの, 浅瀬より上流側 では，下流側境界における塩分が 3 および $5 \%$ の場合と も，浅瀬がない場合の $1 / 2$ 以下であり，下流側境界から の距離の増大とともにその割合は減少する. こうした ことから，かなり小規模な浅瀬であってもその形状に よって塩水の侵入を制御可能であることが判る.

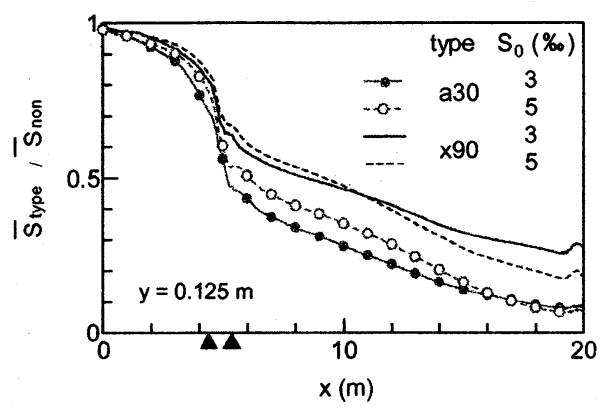

図-7 塩水遡上の制御効率 $(\boldsymbol{\Delta}-\boldsymbol{\Delta}$ : 浅瀬の設置範囲 $)$

\section{4.おわりに}

潮位変動を考慮した塩水楔の遡上に関する 3 次元数 值モデルを開発し，モデル水路を用いた数值解析を行 なうとともに，塩水遡上の制御を目的とした浅瀬を底 設した場合の解析を行い, 塩水遡上の制御効果につい て調べた. 得た結果を要約すると以下の通りである.
(1) 浅瀬の存在によって, shear, 横断・鈶直方向の流速 が増大し混合が強くなり, 塩水の侵入が制御される.

(2)11 種類の浅瀬のうち, 水路中央に最浅部があり側方 ほど水深が増大する type-a 30 の塩水遡上制御効果が最 も高い. なお, 塩水遡上の制御効果が浅瀬の形状に依 存するのは，抵抗特性の違いによる鉛直循環流の変化 のためではないかと考える.

(3) 浅瀬の容積は, 設置区間の全容積（静水時）の $2 \%$ 程 度を占めるが，上流部での水位の上昇も生ぜず，浅瀬周 辺では塩分を最大で $2 / 5-3 / 5$ に低下させることか可能で あることから，有用な制御構造物であると考える.

浅瀬を設置して, 塩水の遡上を人工的に制御する方 法を提案し, 数值解析を通して制御方法の有用性を検 証できた. しかしながら，一様勾配, 水路幅一定のモデ ル水路における解析であり, 現地への適用に対しては, さらに多くの解析を行い基礎的資料を蓄積する必要が ある.

謝辞 : 本研究は, 文部省科学研究費 (基盤研究 (A), No. 10305036, 代表者:田中 仁)および河川整備基金 (河川 環境管理財団)の一部として行われた.

\section{参考文献}

1)Jirka, G.H. and M.Arita:Density currents or density wedge boundary layer influence and control method, J.F.M., Vol.177, pp.187-206, 1987.

2) 小松利光・安達貴浩・孫 双科 - 川上義幸・米須清彦: 感潮 河川における塩水遡上の人工的制御法についての研究, 水 工学論文集, 第 40 巻, pp.517-522, 1996.

3) 伊福 誠・原植利幸 : 気泡噴流による塩水遡上制御の数值 解析, 海岸工学論文集, 第 46 巻 (1), pp.476-480, 1999.

4)Li, C., J.O'Donnel, A.Valle-Levinson, H.Li, K.-C.Wong and K.M.M.Lwiza : Tide induced mass-flux in shallow estuaries, Ocean wave measurement and analysis, Vol.2, pp.1510-1524,1997.

5) 大西亮一・田中康一：河口附近の水源における水質（塩分 濃度）対策について-利根川河口を例として-, 農業土木試 験場技報，第 154 号，WM第 2号，pp.1-63，1983.

6) 藤原広和・沢本正樹・神山尚人 : 複断面水路における河口 密度流の混合特性, 海岸工学論文集, 第 42 巻 (1), pp.416420, 1995.

7) 巽 友正編:乱流現象の科学, 東京大学出版会, p.272, 1986. 8) 伊福 誠・原楨利幸 : 河口密度流の混合特性に及ぼす日潮 不等の影響, 水工学論文集, 第 44 巻, pp.1011-1016, 2000.

9)Li, C. : 3D analytic model for testing numerical tidal models, Jour.Hydraulic Eng., Vol.127, No.9, pp.709-717, 2001. 